\title{
Thinking outside the gundeck: maritime history, the royal navy and the outbreak of British civil war, 1625-42
}

Article

Accepted Version

Blakemore, R. J. (2014) Thinking outside the gundeck: maritime history, the royal navy and the outbreak of British civil war, 1625-42. Historical Research, 87 (236). pp. 251-274. ISSN 0950-3471 doi: https://doi.org/10.1111/1468-2281.12049 Available at https://centaur.reading.ac.uk/71907/

It is advisable to refer to the publisher's version if you intend to cite from the work. See Guidance on citing.

Published version at: http://onlinelibrary.wiley.com/doi/10.1111/1468-2281.12049/full

To link to this article DOI: http://dx.doi.org/10.1111/1468-2281.12049

Publisher: Wiley-Blackwell

All outputs in CentAUR are protected by Intellectual Property Rights law, including copyright law. Copyright and IPR is retained by the creators or other copyright holders. Terms and conditions for use of this material are defined in the End User Agreement.

www.reading.ac.uk/centaur 
Central Archive at the University of Reading

Reading's research outputs online 


\title{
Thinking outside the gundeck: maritime history, the royal navy and the outbreak of British civil war, 1625-1642.*
}

\author{
Richard J. Blakemore \\ University of Exeter
}

Maritime history seems to be suffering an identity crisis. Its recent resurgence in popularity has been widely observed, usually associated with the concurrent rise in scholarship on the Atlantic and Indian Ocean 'worlds', and world and global history, all of which naturally involve substantial maritime elements. ${ }^{1}$ Yet, beyond commending the oceanic perspective, and often praising its potential for overcoming national or imperial narratives, reflections on what this particular sub-discipline is, could or should be offer no consensus on how the historical activities of seafarers can be understood, or their collective role in history. No dominant methodology has emerged for studying the maritime past - and some even question whether one should - though numerous intriguing ideas have been suggested, frequently by social geographers. ${ }^{2}$

Moreover, some advocates for this field are still dissatisfied with what is written under the aegis of maritime history, or fear that its seemingly great potential has not been realized,

\footnotetext{
* I am grateful to the Arts and Humanities Research Council for funding the doctoral research upon which this article is based; to the conveners and audience of the British Maritime History seminar at the Institute of Historical Research for the invitation to speak and the questions they offered; to my fellow conveners of the Maritime and Oceanic History Workshop at Cambridge for innumerable discussions; and to James Davey, Alan James, Simon Layton, Adrian Leonard, Hugh Murphy, David Smith, Edmond Smith and John Walter for commenting upon drafts. This article was runner-up in the 2012 Pollard Prize, awarded to the best paper delivered by a postgraduate student at an I.H.R. seminar.

${ }^{1}$ See, e.g., Fictions of the Sea: Critical Perspectives on the Ocean in British Literature and Culture, ed. B. Klein (Aldershot, 2002 ); Seascapes: Maritime Histories, Littoral Cultures, and Transoceanic Exchanges, ed. J. H. Bentley, R. Bridenthal and K. Wigen (Honolulu, 2007); G. O'Hara, "The sea is swinging into view": modern British maritime history in a globalised world', Eng. Hist. Rev., cxxiv (2009), 1109 - 34; G. Harlaftis, 'Maritime history or the history of the Thalassa', in The New Ways of History: Developments in Historiography, ed. G. Harlaftis, N. Karapidakis, K. Sbonias and V. Vaiopoulos ( 2010 ), pp. 211 - 37; the review essays in Revue d'Histoire Maritime, x-xii (2010); R. Harding, 'The Society for Nautical Research: where are we now and where are we going?', Mariner's Mirror, xcvii (2011), 10 - 21; J. Mack, The Sea: a Cultural History (2011). On Atlantic history, see Atlantic History: a Critical Appraisal, ed. P. D. Morgan and J. P. Greene (Oxford, 2009); The Oxford Handbook of the Atlantic World, c. 1450 - 1850, ed. N. Canny and P. Morgan (Oxford, 2011). On Indian Ocean history, see Maritime India: Rival Empires of Trade in the Orient, 1600 1800, ed. S. Subrahmanyam and others (Oxford, 2004); M. N. Pearson, The World of the Indian Ocean, 1500 1800 (Burlington, 2005); and S. Bose, A Hundred Horizons: the Indian Ocean in the Age of Global Empire (Cambridge, Mass., 2006). On maritime and world and global history, see Maritime History as World History, ed. D. Finamore (New Perspectives on Maritime History and Nautical Archaeology, Gainsville, Fla., 2004); Maritime History as Global History, ed. M. Fusaro and A. Polónia (St. John's, Newfoundland, 2012).

${ }^{2}$ See especially the collected essays in the 'Oceans connect' volume of the Geographical Rev., lxxxix (1999); P. E. Steinberg, The Social Construction of the Ocean (Cambridge, 2001); M. Ogborn, 'Editorial: Atlantic geographies', Social and Cultural Geography, vi (2005), 379 - 85; D. Lambert, L. Martins and M. Ogborn, 'Currents, visions, and voyages: historical geographies of the sea', Jour. Historical Geography, xxxii (2006), 479 - 93; L. Johnman and H. Murphy, 'Maritime and business history in Britain: past, present and future?', International Jour. Maritime Hist., xix (2007), 239 - 70, at pp. 241, 269.
} 
or might be overstated. ${ }^{3}$. Another concern is that, for all the developments of the last two decades, it has yet to have its rightful place acknowledged by other scholars, perhaps because the term 'maritime history' has not entirely escaped the connotations of antiquarian interest in nautical detail and naval hagiography, particularly in Britain where the royal navy continues to dominate the popular imagination of the seafaring past. ${ }^{4}$ Whether these anxieties are justified or not, at least in anglophone scholarship, naval studies preponderate, and in both naval and maritime history there is much greater concentration on the eighteenth century and after, for which records are vastly more plentiful.

Despite the recent vitality of maritime history, innumerable specific studies of seafarers and wide recognition of their local and global significance in economic terms, seafarers and their place in the past remain marginal to mainstream historical scholarship. If the lack of coherence among maritime scholars is one reason for this marginalization (and this very diversity could well be maritime history's greatest strength), another explanation might be the popularity of the stereotype, evident in European culture from the medieval period onwards, of the 'seaman' as totally separate, isolated and unfathomable to contemporaries, a cultural trope that seafarers themselves deployed, and which still endures. ${ }^{5}$

This stereotype is evident in some, though by no means all, writings on the royal navy, including a quite recent addition to the 'Jack Tar' tradition, which takes an eighteenthand nineteenth-century image and applies it to seafarers throughout history. ${ }^{6}$ It is perhaps also

\footnotetext{
${ }^{3}$ Compare the objectives set out in L. R. Fischer and H.W. Nordvik, 'The context of maritime history: the new International Journal of Maritime History', International Jour. Maritime Hist., i (1989), vi-ix, and the criticisms in L. R. Fischer, 'Are we in danger of being left with our journals and not much else: the future of maritime history?', Mariner's Mirror, xcvii (2011), 366 - 81; see also M. Fusaro, 'Maritime history as global history? The methodological challenge and future research agenda', in Fusaro and Polónia, pp. 267 - 82.

${ }^{4}$ This is apparent in Fischer, 'Are we in danger'; Johnman and Murphy; and R. Gorski, 'Roles of the sea: the view from the shore', in Roles of the Sea in Medieval England, ed. R. Gorski (Woodbridge, 2012), pp. 1 - 24; Harding, 'Society for Nautical Research', is considerably more positive. On naval history in Britain, see N. A. M. Rodger, 'Britain', in Ubi Sumus? The State of Naval and Maritime History, ed. J. Hattendorf (Newport, R.I., 1994), pp. 41 - 57; N. A. M. Rodger, 'Historiographical review: recent work in British naval history, 1750 - 1815', Historical Jour., li (2008), 741 - 51; N. Rodger, Essays in Naval History, from Medieval to Modern (Farnham, 2009); R. Knight, 'Changing the agenda: the new naval history of the British sailing navy', Mariner's Mirror, xcvii (2011), 225 - 42; D. Leggett, 'Navy, nation and identity in the long 19 the century', Jour. Maritime Research, xiii (2011), 151 - 63. I am grateful to James Davey for directing me to this last item. Both of these concerns were also apparent in discussions at the International Maritime and Economic History Association's 6 the International Congress of Maritime History, University of Ghent, 2 - 6 July 2012.

${ }^{5}$ This is explored in more depth in R. J. Blakemore, 'The London and Thames maritime community during the British civil wars, 1640 - 9' (unpublished University of Cambridge Ph.D. thesis, 2012).

${ }^{6}$ This is a very strong tradition: see especially C. Lloyd, The British Seaman, 1200 - 1800: a Social Survey (1968); J. Laffin, Jack Tar: the Story of the British Sailor (1969); P. Kemp, The British Sailor: a Social History of the Lower Deck (1970); the most recent of this kind is B. Lavery, Royal Tars: the Lower Deck of the Royal Navy, $875-1850$ (2010). There is a considerably more advanced scholarship on the navy, especially for the 18 th century and after, for which see the sources cited in n. 4 above. For an international perspective, see A. James, 'Raising the profile of naval history: an international perspective on early modern navies', Mariner's Mirror, xcvii (2011), 193 - 206.
} 
encouraged by those scholars such as Jesse Lemisch, and those influenced by him, who in adopting a Marxist perspective define seafarers in primarily economic terms, placing them in a confrontational model with the capitalist society ashore which drove demand for their labour. ${ }^{7}$ It may be significant that these scholars, while rejecting some aspects of the stereotype, still use the term 'Jack Tar' not to describe a cultural phenomenon but to refer to real seafarers. Even if the term is mostly absent from economic maritime history, here too individual seafarers are indistinct in a statistical mass. ${ }^{8}$ In this emphasis on the isolation and homogeneity of seafarers, the three very different ways of seeing the past which primarily inform maritime history, and possibly account for the identity crisis - the nation-state focused study of navies, the quantitative approach of economics, and the trans- or even anti-national impulses of oceanic, world and global history - perhaps share more than they realize.

It is the argument of this article that these perspectives, by relying on the stereotype or by reducing seafarers' interests to primarily economic motivations, have not given sufficient consideration to critically important relationships between seafarers and shore society. What some have chosen to call the 'new maritime history', with its emphasis on the social history of seafarers, has been more attentive to interactions between seafarers and societies, but this has not yet gone far enough. ${ }^{9}$ These connections must be central to our investigations if we are truly to understand seafarers in history.

\footnotetext{
${ }^{7}$ J. Lemisch, 'Jack Tar in the streets: merchant seamen in the politics of revolutionary America', William \& Mary Quarterly, xxv (1968), 371 - 407; J. Lemisch, Jack Tar vs. John Bull: the Role of NewYork's Seamen in Precipitating the Revolution (New York, 1997). Most notable among Lemisch's followers is Marcus Rediker, especially his Between the Devil and the Deep Blue Sea: Merchant Seamen, Pirates, and the Anglo-American Maritime World, 1700 - 50 (Cambridge, 1987); see also P. Linebaugh, “"Jack Tar in history”, Halifax, Nova Scotia. October 15 - 18, 1990 ', History Workshop, xxxii (1991), 217 - 21.

${ }^{8}$ Memorial University, Newfoundland has produced much of the best recent economic maritime history: see especially People of the Northern Seas, ed. L. R. Fischer and W. Minchinton (St. John's, Newfoundland, 1992); The Market for Seamen in the Age of Sail, ed. L. R. Fischer (St. John's, Newfoundland, 1994); 'Those Emblems of Hell'? European Sailors and the Maritime Labour Market, 1570 - 1870, ed. P. C. van Royen, J. R. Bruijn and J. Lucassen (St. John's, Newfoundland, 1997); and also The North Sea: Twelve Essays on Social History of Maritime Labour, ed. L. R. Fischer, H. Hamre, P. Holm and J. R. Bruijn (Stavangar, 1992); R.W. Unger, Ships and Shipping in the North Sea and Atlantic, 1400 - 1800 (Aldershot, 1997); and Shipping and Economic Growth, 1350 - 1850, ed. R. W. Unger (Leiden, 2011).

${ }^{9}$ For an overview of the 'new maritime history', see V. J. Patarino, 'The religious shipboard culture of 16th- and 17th-century English sailors', in The Social History of English Seamen, 1485 - 1649, ed. C.A. Fury (Woodbridge, 2012), pp. 141 - 92 , at pp. 142 - 51; key pieces include V. Burton, 'The myth of bachelor Jack: masculinity, patriarchy and seafaring labour', in Jack Tar in History: Essays in the History of Maritime Life and Labour, ed. C. Howell and R. J. Twomey (Fredericton, New Brunswick, 1991), pp. 179 - 98 ; and D. Vickers, 'Beyond Jack Tar', William \& Mary Quarterly, 1 ( 1993), 418 - 42; see also D. Vickers, Young men and the Sea: Yankee Seafarers in the Age of Sail (2005); and Seafarer and Community: Towards a Social Understanding of Seafaring, ed. P. H. Fricke (1973). Some among the 'new maritime history' have also continued to use 'Jack Tar', e.g. C. Fury, Tides in the Affairs of Men: the Social History of Elizabethan Seamen, 1580 - 1603 (2002); and Fury, Social History of English Seamen. This trend may already have gone further for the later period (see the discussion in Leggett).
} 
This argument will be explored here by an analysis of British seafarers' activities during the early years of Britain's mid seventeenth-century revolutionary decades, when their involvement in popular politics renders their connections with society particularly clear. Lemisch, one of the earliest leaders of the 'new maritime' movement, discussed the involvement of seamen in the American revolution, portraying them as 'outcasts, men with little hope of success ashore ... these were the rebels' who, in reaction first to impressment then to the Stamp Act, became revolutionaries. ${ }^{10}$ Marcus Rediker and Peter Linebaugh have likewise described sailors as part of the 'Atlantic proletariat' which, they argue, was critical to the 'age of revolutions' in the later eighteenth century; but they also push this interpretation back to the English revolution of the sixteen-forties. ${ }^{11}$. Yet very little detailed work has been done on the role of seafarers in the popular politics of that decade. Indeed, naval scholars have sometimes dismissed the early seventeenth century altogether, and usually explain the fact that the royal navy sided against the king mostly in terms of internal naval affairs, or as a result of naval politics in which some officers were more successful than others in 'seizing the fleet'. ${ }^{12}$

Focusing on the outbreak of civil war in 1640-2 (depending on who you believe, either the English revolution, or the first of a series), this article explores the evidence for seafarers' involvement in the escalation into violent conflict. ${ }^{13}$ More importantly, it asks what this reveals about their relationship to society more generally during the early modern period, especially the extent to which that relationship was shaped by their vocational maritime identity and their economic interests. To do so, it takes a broader approach and considers the experience of the maritime community, principally those based in London, throughout the reign of Charles I. Given the emphasis placed by historians on the choice of the royal fleet to side with parliament in July 1642 as a barometer of attitudes in the maritime community more generally, the article will examine the interpretations presented by historians of the reasons behind this decision, and why these are unsatisfactory. Then, it will survey the

\footnotetext{
${ }^{10}$ Lemisch, 'Jack Tar', p. 377.

${ }^{11}$ P. Linebaugh and M. Rediker, The Many-Headed Hydra: Sailors, Slaves, Commoners, and the Hidden History of the Revolutionary Atlantic (2000).

${ }^{12}$ See the more detailed discussion below.

${ }^{13}$ David Cressy has argued that 'a revolution caused the war, not the war brought about the revolution', in his 'Revolutionary England, 1640 - 2', Past \& Present, clxxxi (2003), 35 - 71, at p. 40; see also D. Cressy, England on Edge: Crisis and Revolution 1640 - 2 (Oxford, 2006). For the more traditional view that $1640-2$ witnessed the first of numerous revolutions, see C. Russell, 'Introduction', in The Origins of the English Civil War, ed. C. Russell (Basingstoke, 1973), pp. 1 - 32 , at p. 2; J. Morrill, 'Introduction', in Reactions to the English Civil War, 1642 - 9, ed. J. Morrill (1982), pp. 1 - 27 , at p. 1. Cf. Austin Woolrych's theory of several 'climacterics' within a longer revolution; see his Commonwealth to Protectorate (Oxford, 1982), pp. 1 -2, for a brief outline of this argument; it is also employed throughout A. Woolrych, Britain in Revolution, $1625-60$ (Oxford, 2002).
} 
available evidence for seafarers' participation in both popular and local political agitation, comparing riots during the sixteen-twenties with those of the sixteen-forties. This evidence compellingly shows that seafarers were actively engaged in the political debates of the early sixteen-forties not only for economic reasons, or as a form of class conflict, but because of more complex social interactions, particularly through a shared religious identity. Finally, the conclusion will reflect on the implications of this particular study for the practice of naval and maritime history.

When most of the royal fleet sided with parliament in the summer of 1642 , it was in immediate terms the outcome of a political wrangle over the appointment of officers. On 1 July 1642, the earl of Northumberland presented to parliament a letter from the king in which he was discharged from his post as lord admiral. ${ }^{14}$ That same day 'for the Safety of His Majesty's Person, the Parliament and Kingdom, in this Time of imminent Danger', parliament nominated the earl of Warwick, an influential figure in opposition and well connected to merchants and seafarers through his investment in privateer and colonial voyages, to 'command in chief the Ships of the Fleet now at Sea'. ${ }^{15}$ In fact Warwick was already effectively in command, parliament having required Northumberland to appoint him as his deputy in March. ${ }^{16}$ Charles had opposed this decision in favour of Sir John Pennington, a naval officer of long standing, who had been vice-admiral during the sixteen-thirties; parliament, however, ignored these objections. ${ }^{17}$ When Charles later dismissed Northumberland, this was, according to the royalist memoirist the earl of Clarendon, mainly intended to remove Warwick. ${ }^{18}$ The king wrote to Warwick on 28 June to declare void his appointment by Northumberland, and also to officers at the Chatham dockyards, and to the captains of the fleet, ordering them to obey Pennington rather than Warwick. ${ }^{19}$

\footnotetext{
${ }^{14}$ Lords Journal, v. 169.

${ }^{15}$ L.J., v. 174; Commons Journal, ii. 647, 650. S. Kelsey, 'Rich, Robert, 2 nd earl of Warwick (1587 - 1658)', Oxford Dictionary of National Biography (Oxford, 2004) <http://www.oxforddnb.com/view/article/23494> [accessed 12 Feb. 2013]; a detailed account of Warwick's role in $1640-2$ is given in J. Adamson, The Noble Revolt: the Overthrow of Charles I (2007). For the journal of one of these privateer voyages, which Warwick himself commanded, see W. Ball, 'Might and would not', pr. in 'The earl of Warwick's voyage in 1627', ed. N. P. Bard, in The Naval Miscellany, v, ed. N. A. M. Rodger (1984), 15 - 93.

${ }^{16}$ L.J., iv. 645; L.J., v. $20-1,70-2,80,85,91$; C.J., ii. 474, 478.

17 L.J., iv. 665, 695, 676, 697; C.J., ii. 495, 499 - 500, 509 - 10; A Message from Both Hovses of Parliament...that the Earle of Warwick might Command this Summers Fleet (2 Apr. 1642). On Pennington, see A. Thrush, 'Pennington, Sir John (bap. 1584?, d. 1646)', O.D.N.B. <http://www.oxforddnb.com/view/article/21842> [accessed 12 Feb. 2013].

${ }^{18}$ Edward Hyde, earl of Clarendon, The History of the Rebellion and Civil Wars in England Begun in the Year 1641, ed. W. Dunn Macray (6 vols., Oxford, 1888 ; repr. 1992), ii. 209 - 16.

${ }^{19}$ L.J., v. $178-80,223$.
} 
Pennington, after some hesitation, carried the letters to the fleet, arriving on 2 July; but, rather than go to the fleet himself, he sent Sir Henry Palmer, another former naval officer, to express the king's commands to the captains. ${ }^{20}$ Alerted to this danger, Warwick called a council of war at which seventeen captains and masters pledged their support for him and for parliament's ordinance appointing him. Five captains - all of whom had served in the navy during the sixteen-thirties - wrote to Warwick explaining that they could not disobey the king. ${ }^{21}$ One of these subsequently submitted to Warwick, who surrounded the four other ships, ordering them to surrender; two did. According to Warwick's account, the response of the last two captains was 'so peremptory' and 'my Masters and sailors grew so impatient on them' that, despite being unarmed, they boarded and seized both captains and their ships. ${ }^{22}$

These five captains were promptly declared 'delinquents', and three of them were brought to parliament. ${ }^{23}$ On 7 July, parliament ordered all 'Ships that are in the Service of the State' to obey Warwick. ${ }^{24}$ Despite Charles's attempt on the same day to scotch parliament's plans by forbidding the principal administrative officers of the navy to obey his opponents, parliament's naval preparations continued apace, and they successfully captured a few other naval vessels. ${ }^{25}$ This contest for the control of military forces, though it was less widely debated than the concurrent militia controversy, also accelerated the coming of civil war in England and to some extent shaped the conflict that ensued. ${ }^{26}$ The contradictory demands made by king and parliament both used a language of general appeal but articulated a clear division, forcing seafarers to make difficult decisions and become combatants even before war was declared.

\footnotetext{
20 On Palmer, see R. McCaughey, 'Palmer, Sir Henry (bap. 1582 , d. 1644)', O.D.N.B. <http://www.oxforddnb.com/view/article/65990> [accessed 12 Feb. 2013].

${ }^{21}$ For the pre-war careers of these officers, see D. Kennedy, 'Naval captains at the outbreak of the English civil war', Mariner's Mirror, xlvi (1960), 181 - 98.

${ }^{22}$ These events are described in Warwick's letters in L.J., v. $178-80$, 185, which were published in A letter sent from the right honorable Robert earle of Warwik (6 July 1642), printed in two separate editions (Another declaration of the Lords and Commons... and a letter from the earle of Warwick (7 July 1642), sig. A $1 \mathrm{v}$; and The earl of VVarwicks letter from aboard his majesties ship, called the James (7 July 1642)); another, shorter, parliamentarian account was published in The kings majesties resolvtion concerning, Robert earl of Warwicke (12 July 1642).

${ }^{23}$ Sir John Mennes, the rear-admiral, protested that 'as soon as he heard that...Warwick had an Ordinance of Parliament', he willingly submitted (L.J., v. 189 - 90; cf. pp. 195, 218 - 19).

${ }^{24}$ L.J., v. 188; C.J., ii. 654, 657.

${ }^{25}$ For Charles's orders, see L.J., v. 224; for naval preparations, see L.J., v. 194, 198 - 9, 206, 213, 216; C.J., ii. 670, 678, 723; Anon., The parliaments desires to the earl of Warwicke (21 July 1642).

${ }^{26}$ For the militia in London, see K. Lindley, Popular Politics and Religion in Civil War London (Aldershot, 1997), pp. 199 - 211; L. Nagel, “'A great bouncing at every man's door”: the struggle for London's militia in 1642', in London and the Civil War, ed. S. Porter (Basingstoke, 1996), pp. 65 - 88; for the wider debates, see I. Gentles, The English Revolution and the Wars in the Three Kingdoms, 1638 - 1652 (Harlow, 2007), pp. 91 105; M. Braddick, God's Fury, England's Fire: a New History of the English Civil Wars (2008), pp. 186 - 238.
} 
Most historians' accounts of these events, including in general discussions of the civil wars or of the navy, have followed Clarendon's focus on Pennington and Warwick as the key actors in the drama, usually contrasting Pennington's indecision with Warwick's dynamic resolve, though Pennington and Palmer are often excused on the grounds of their old age. ${ }^{27}$ Descriptions of the fleet as 'seized' or 'lost' neatly encapsulate this assumption that the important political actions were taken by the commanding officers, and perhaps the captains; that the fleet was merely waiting around to be seized. Even though Stephen Greenberg, for example, argued that "what was "lost" by the king, or "seized" by parliament, was not ships but the allegiance of those on board', this still reduces the sailors' political agency essentially to a responsive role. ${ }^{28}$

Where any analysis of the motivation of sailors in these political decisions is offered, it usually revolves around the treatment of naval sailors, assuming that seafarers' decisions were determined only by issues internal to their profession. This was first argued by Michael Oppenheim in his influential nineteenth-century study of the Tudor and Stuart navy, and adopted practically wholesale by John Powell in his book on the civil war navy, as well as more recently by Greenberg and others. ${ }^{29}$ The assumption is that sailors were either incapable of understanding, or were uninterested in, the debates taking place throughout Britain about the relationship between king and parliament, church and state. According to Powell they were 'simple, blunt, childlike men, upon whose minds the hardships of poverty, hunger and cold weighed heavily, to the exclusion of everything else. They were matter-of-fact individuals with the greater part of their attention fixed on pay and food'.$^{30}$ The origins of this theory very likely lie in the condescending, and largely puzzled, descriptions offered by

\footnotetext{
${ }^{27}$ Clarendon, ii. 216 - 26; M. Oppenheim, A History of the Administration of the Royal Navy and of Merchant Shipping in Relation to the Navy from MDIX to MDCLX (1896), pp. 240 - 1; J. R. Powell, The Navy in the English Civil War (Hamden, Conn., 1962), pp. 19 - 22; A. D. Thrush, 'The navy under Charles I, 1625 - 40' (unpublished University of London Ph.D. thesis, 1990), pp. 39 - 44; K. Andrews, Ships, Money and Politics: Seafaring and Naval Enterprise in the Reign of Charles I (Cambridge, 1991), pp. 184 - 6, though see also pp. $80-1$; S. J. Greenberg, 'Seizing the fleet in 1642 : parliament, the navy, and the printing press', Mariner's Mirror, lxxvii (1991), 227 - 34, at pp. 229 - 31 . For general accounts, see R. Harding, The Evolution of the Sailing Navy, 1509 - 1815 (Basingstoke, 1995), pp. 58 - 62 ; N. A. M. Rodger, The Safeguard of the Sea: a Naval History of Britain, 660 - 1649 (1997), pp. 414 - 15; Gentles, pp. 95 - 6; Braddick, pp. 214 - 15.

${ }^{28}$ Greenberg, pp. 227, 233.

${ }^{29}$ Oppenheim, History of the Administration, pp. 222, 230, 241 - 3; Powell, pp. 10 - 11, is based almost entirely on Oppenheim; it is also the interpretation favoured by Donald Kennedy in his thesis, 'Parliament and the navy, 1642 - 8: a political history of the navy during the civil war' (unpublished University of Cambridge Ph.D. thesis, 1959), pp. 17 - 28; Greenberg. For its appearance elsewhere, see G. E. Mainwaring, 'The dress of the British seaman', Mariner's Mirror, ix (1923), 322 - 32, at p. 322; Lloyd, p. 52; Laffin, p. 8; Kemp, p. 23; Lavery, p. 61; J. Scott, When the Waves Ruled Britannia: Geography and Political Identities, 1500 - 1800 (Cambridge, 2011), pp. $70-2$.

${ }^{30}$ Powell, p. 11. Here, Powell is paraphrasing Oppenheim, History of the Administration, pp. $240-1$.
} 
Clarendon, who as a royalist peer was not exactly disposed to empathize with parliamentarian seafarers. ${ }^{31}$

Charles's neglect of the seamen - following a period of administrative corruption and naval inaction under his father - therefore drove them into the arms of parliament. ${ }^{32}$ Greenberg asserts that 'Charles spent money on the ships themselves, not on the men who sailed them'. ${ }^{33}$ This interpretation is essentially based upon the catalogue of mistreatment collected by Oppenheim, who certainly provided ample evidence of administrative inefficiency and corruption which resulted in unhealthy food, insufficient supplies and irregular pay. ${ }^{34}$ This situation, it is argued, so disenchanted the sailors of the navy that the prospect of regular pay and supplies offered by parliament in 1642 was irresistible. Yet, as Oppenheim himself tacitly acknowledged that conditions may have improved during the sixteen-thirties, his account, and those of his followers, encounter substantial problems as an explanation for the events of the sixteen-forties. ${ }^{35}$

Moreover, the fleet was always a minority of the population of the British maritime community. Andrew Thrush suggested a naval population of between 5,000 and 10,000 in the war years of 1625 - 30, dropping with the conclusion of peace and then rising again to somewhere around 4,500 in the later sixteen-thirties. ${ }^{36}$ Thrush, Christopher Lloyd and Kenneth Andrews estimated the total number of seafarers in England (not Britain) at 20 25,000 in 1629, a low point due to the preceding war years, and both Andrews and Thrush posited that considerable expansion occurred in the next decade. ${ }^{37}$ Therefore, the navy never employed at one time more than half, and usually less than a quarter, of English, let alone British, seafarers.

The frequent fluctuation in naval personnel may have drawn in larger numbers of seafarers than these estimates suggest, but if it did, it also reduced the amount of time they were likely to spend in the navy. Some officers, including warrant officers, did remain in naval service for a long time, or at least claimed to have done so when petitioning the

\footnotetext{
${ }^{31}$ Clarendon, ii. 223, $225-6$.

${ }^{32}$ For corruption under James, see The Jacobean Commissions of Enquiry, 1608 - 18, ed. A. McGowan (1971); Rodger, The Safeguard of the Sea, ch. 25; for a more sympathetic account of the Jacobean navy, see E. Milford, 'The navy at peace: the activities of the early Jacobean navy', Mariner's Mirror, lxxvi (1990), 23 - 36.

${ }^{33}$ Greenberg, p. 228.

${ }^{34}$ Oppenheim, History of the Administration, pp. 216 - 39; however, on pay, see A. P. McGowan, 'The navy under the first duke of Buckingham, lord high admiral 1618 - 28' (unpublished University of London Ph.D. thesis, 1967), pp. 116 - 21; see also A. Coats, 'English naval administration under Charles I - top-down and bottom-up - tracing continuities', Trans. Naval Dockyards Soc., viii, ed. R. Riley (Portsmouth, 2012), 9 - 30.

${ }^{35}$ Oppenheim, History of the Administration, pp. 236, 238 - 9.

${ }^{36}$ Thrush, 'The navy under Charles I', pp. $202-6$.

${ }^{37}$ Lloyd, pp. $54-5$; Thrush, 'The navy under Charles I', p. 205; Andrews, pp. $221-2$.
} 
admiralty. ${ }^{38}$ However, the continuation throughout this period of impressment, the complaints that men absented themselves from service, and the proclamations forbidding them to do so, show that new sailors were constantly needed. ${ }^{39}$ Pennington's journal for the sixteen-thirties records regular pressing of sailors, often to replace men he was simultaneously discharging. ${ }^{40}$ If we are to believe the complaints of some naval officers, pressing often brought in men from a wide range of backgrounds, not just sailors. ${ }^{41}$

The amount of seafarers who, in 1642, would have memories of naval service during the difficult years of the later sixteen-twenties and early sixteen-thirties is therefore questionable. ${ }^{42}$ This is supported by the youth of many seafarers; a large proportion of those at sea in the sixteen-forties would have been infants two decades earlier. Of London seafarers appearing in the admiralty court in $1640-2,60$ per cent were under thirty-five, of whom approximately one-third were under twenty-five, and another third aged between twenty-five and thirty. ${ }^{43}$ Seafaring careers could begin before the age of twenty, so it is possible that some of these men had formative experiences of neglect in the Caroline navy; but it seems quite unlikely that all or even many of them did. ${ }^{44}$ Also, a large proportion of the maritime community appear to have been only temporary, moving between seafaring and other trades, so that even older seafarers from the sixteen-forties may not have been at sea during the sixteen-twenties. ${ }^{45}$

Considering both the youth and occupational mobility of many seafarers, and the irregular nature of naval service, it seems probable that only some - perhaps even very few of those present in the fleet in 1642 would have memories of the neglect of the sixteentwenties and early sixteen-thirties, and this explanation for the support for parliament begins to look a little thin. Those who did have such memories would be older and more experienced and may therefore have had some influence on the opinions of younger men in the fleet. The fact that some officers such as boatswains and masters who served parliament during the

\footnotetext{
${ }^{38}$ E.g., Calendar of State Papers, Domestic, 1631 - 3, pp. 2, 5, 8, 91, 141, 147, 212, 272 - 3, 293, 352 - 3, 401 - 2, 433, 436, 508, 511, 545, 559-60, 561.

${ }^{39}$ National Maritime Museum (hereafter N.M.M.), ADL/J/3; The National Archives of the U.K.: Public Record Office (hereafter T.N.A.: P.R.O.), SP 16/228 fo. 68v; SP 16/264 fos. 6r, 117v; Cal. S.P. Dom. 1625 - 6, pp. 237, 357; Cal. S.P. Dom. 1628 - 9, pp. 159, 162; Cal. S.P. Dom. 1631 - 3, p. 355; Cal. S.P. Dom. 1635 - 6, pp. 404, 554 .

${ }^{40}$ N.M.M., JOD/1/1 fos. 6v, 7v - 8v, 9v - 10r, 11r, 27r, 31v, 35r, 63v, 67r.

${ }^{41}$ E.g., Cal. S.P. Dom. 1628 - 9, p. 228; N.M.M., JOD/1/1 fos. $86 \mathrm{v}-7 \mathrm{r}$.

42 This point is made in Rodger, The Safeguard of the Sea, p. 403.

43 T.N.A.: P.R.O., HCA 13/56, 13/57 .

${ }^{44}$ The evidence for the age of commencing a seafaring career is discussed in detail in Blakemore, pp. $34-6$.

${ }^{45}$ R. Davis, The Rise of the English Shipping Industry in the 17th and 18th Centuries (Newton Abbot, 1971), p. 116; Fury, Tides in the Affairs of Men, pp. $197-8$.
} 
$1640 \mathrm{~s}$ had had long careers in the navy, some for a number of decades, supports this. ${ }^{46}$ Yet even if some sailors did serve continuously in the royal fleet for three decades, this does not necessarily mean that they harboured a burning resentment against both the navy and the king. Indeed, at a time when alternative maritime employment was readily available, and usually much more generously paid, long naval service would suggest the opposite. ${ }^{47}$. Moreover, while complaints of neglect and discontent continue into the early sixteen-thirties, including those concerning pay owed from the sixteen-twenties, they become progressively less numerous and strident. ${ }^{48}$ Partially this was a result of peace: the administration was not subjected to the same debilitating strain as it had been during the war years of the previous decade.

It was also the outcome of Charles's sustained campaign to expand and improve the navy, extending central control and combating corruption, and raising the controversial 'ship money' levy to fund large, regular fleets, which provided much-needed experience. ${ }^{49}$ Charles also raised the pay of sailors for the first time since Elizabeth, which in his opinion should have ensured their loyalty - it seems that he, too, misjudged the motivations of seafarers. ${ }^{50}$ More recently historians have been less condemnatory in their judgements of Charles's naval activity during the sixteen-thirties. ${ }^{51}$ While it is perhaps dangerous to argue from silence, the lack of organized complaint during the later sixteen-thirties, considering that sailors were prepared to protest so volubly during the sixteen-twenties, suggests that conditions had improved, or that too few sailors were now affected by them to result in widespread protest. Therefore, though memories of past mistreatment might have motivated some sailors during the sixteen-forties, this alone cannot explain why the sailors of the fleet chose to support parliament.

\footnotetext{
${ }^{46}$ E.g., T.N.A.: P.R.O., ADM 18/3 fo. 19v; SP 16/494 fo. 103r; SP 16/504 fo. 33r; SP $16 / 509$ fos. 14r, 53r, 72r.

${ }^{47}$ On comparative rates in naval and merchant ships, see Oppenheim, History of the Administration, pp. 243 - 4; Kennedy, 'Parliament and the navy', pp. 22 - 8; Thrush, 'The navy under Charles I', pp. 212 - 13; Andrews, pp. $76-7$.

${ }^{48}$ Cal. S.P. Dom. 1629 - 31, pp. 328, 338, 538; Cal. S.P. Dom. 1631 - 3, pp. 89, 172, 380; Cal. S.P. Dom. 1633 - 4, p. 215; Cal. S.P. Dom. 1634 - 5, pp. 19, 28, 73, 101.

${ }^{49}$ On the navy in the 1630s, see B. Quintrell, 'Charles I and his navy in the 1630s', Seventeenth Century, iii (1988), 159 - 79; Thrush, 'The navy under Charles I'; Andrews, ch. 6; Rodger, The Safeguard of the Sea, chs. $26-7$.

${ }^{50}$ On pay, see Oppenheim, History of the Administration, pp. 225 - 6. For Charles's opinion of the sailors, see Clarendon, p. 225; Charles I, By the king. A proclamation of his majesties grace, favour, and pardon to all seamen, sailers, marriners and other water-men (Oxford, 1642).

${ }^{51}$ E.g., Quintrell; Thrush, 'The navy under Charles I'; Andrews, pp. 158 - 9; Rodger, The Safeguard of the Sea, p. 383.
} 
Another interpretation has been advanced by Nabil Matar who, as an expert on Ottoman and north African history, brings a valuable international perspective, and whose suggestions are more persuasive because they are relevant to the whole maritime community, though they are essentially another variation on the 'neglect' theme which again assumes that seafarers were primarily occupied by maritime issues. ${ }^{52}$ His argument does not in fact relate explicitly to the July episode when the fleet sided with parliament, but rather to the causes of the civil war as a whole. Matar points to the rise in the activity of north African corsairs, both within the Mediterranean and in the Atlantic, which created a 'crisis of captivity' for European sailors. ${ }^{53}$ Large numbers of European seafarers were captured and spent some time imprisoned or enslaved in Tunis, Algiers or other Maghreb ports: David Hebb estimates that some 7,000 English captives were taken in 1622-42. ${ }^{54}$

Under Elizabeth, Matar argues, a number of policies had been pursued to counter this threat, including state-supported ransoms for captured seafarers. By contrast, the early Stuart governments failed to provide similar schemes, allowing sailors to remain imprisoned despite repeated petitions from their wives and families. ${ }^{55}$ It was during Charles's reign, too, that Magharibi corsairs attacked Britain itself in raids which carried away captives from Lundy and Baltimore. ${ }^{56}$ Matar may be right to suggest that these developments created a sense of danger, and disappointment with the royal government, in the merchant and maritime communities, though his claims for their role in causing the civil wars are perhaps overstated. ${ }^{57}$

However, the situation was not such a clear case of decline from Elizabethan to Stuart times, which is a common narrative in maritime history. ${ }^{58}$ Though he was, perhaps, not as committed as Elizabeth to protecting British seafarers, or at least less successful at it, Charles did pursue some policies to guard the maritime community. In 1626 he concluded a peace with Salé which saw the release of all English prisoners, though hostilities were later

\footnotetext{
${ }^{52}$ N. Matar, 'Wives, captive husbands and Turks: the first women petitioners in Caroline England', Explorations in Renaissance Culture, xxiii (1997), 111 - 29; N. Matar, 'English accounts of captivity in north Africa and the Middle East: 1577 - 1625 ', Renaissance Quarterly, liv (2001), 553 - 72; N. Matar,'The Barbary corsairs, King Charles I and the civil war', Seventeenth Century, xvi (2001), 239 - 58; and N. Matar, Britain and Barbary, 1589 - 1689 (Gainsville, Fla., 2005).

${ }^{53}$ Matar, Britain and Barbary, pp. $78-80$.

${ }^{54}$ D. D. Hebb, Piracy and the English Government, 1616 - 42 (Aldershot, 1994), p. 139.

${ }^{55}$ Matar, 'English accounts of captivity', pp. 560 , 564 , 569; for petitions, see Matar, 'Wives, captive husbands and Turks'; G. G. Harris, Trinity House of Deptford Transactions, 1609 - 35 (1983), pp. 66, 70 - 1, 76 - 7; Cal. S.P. Dom. 1625 - 6, p. 516.

${ }^{56}$ H. Barnby, 'The Algerian attack on Baltimore in 1631', Mariner's Mirror, lvi (1970), 27 - 31; Cal. S.P. Dom. $1625-6$, p. 89.

${ }^{57}$ Matar, 'Barbary corsairs'; Matar, Britain and Barbary, pp. 8, 38 - 9, 65 - 7, 74.

${ }^{58}$ See Harding, The Evolution of the Sailing Navy, pp. 33, 49.
} 
renewed. ${ }^{59}$ An expedition led by William Rainsborough blockaded Salé in 1637 and, though this did not destroy that corsair base, it did result in the release of 293 English captives. ${ }^{60}$ Rainsborough certainly thought it successful enough to suggest a similar action against Algiers the following year, though this never took place, probably due to the developing British crisis. ${ }^{61}$ Matar's argument is also focused very narrowly upon the activities of those based in the Maghreb, but the actions of European forces, most importantly those based at Dunkirk, would also have contributed to any sense of vulnerability among the seafaring community, even if Europeans were less interested in capturing sailors for ransom. ${ }^{62}$ Certainly, in 1640-2, there were complaints about Dunkirk and Calais as well as Algiers or Tunis. ${ }^{63}$

In addition, Matar's argument may have unexplored implications for our understanding of the 'ship money' fleets. The government justified collection of 'ship money' by the emergency situation, claiming it was intended explicitly to counteract piracy and to protect British trade. This has often been seen by historians as a duplicitous pretext for a navy which was, in effect, a diplomatic tool aimed against the Dutch and French (Kenneth Andrews also dismisses Rainsborough's expedition as a 'side-show'). ${ }^{64}$ It seems, however, that this is over-emphasizing a distinction not necessarily understood at the time, and giving too much attention to the complaints of particular officers, among them Pennington. ${ }^{65}$ Certainly, as vice-admiral, Pennington was well placed to comment on the affairs of the fleets, but other officers passed more positive judgements, Sir William Monson claiming that they 'produced both renown and safety to [Charles] and [his] realm'. ${ }^{66}$ Even Pennington acknowledged in 1636 that he had sailed along the western coast neither meeting nor hearing

\footnotetext{
${ }^{59}$ T.N.A.: P.R.O., HCA $13 / 52$ fo. $265 \mathrm{v}$.

${ }^{60}$ See Andrews, ch. 7; Hebb, Piracy, pp. $237-65$.

${ }^{61}$ Cal. S.P. Dom. $1637-8$, p. 187.

${ }^{62}$ For European pirates, see Hebb, Piracy; J. C. Appleby, 'A nursery for pirates: the English pirate community in Ireland in the early 17th century', International Jour. Maritime Hist., ii (1990), 1 - 27; R.A. Stradling, The Armada of Flanders: Spanish Maritime Policy and European War, 1568 - 1668 (Cambridge, 1992); P. Villiers, Les Corsairs du littoral: Dunkerque, Calais, Boulogne de Phillipe II à Louis XIV (1568 - 1713) (Calais, 2000). English sailors were imprisoned in Dunkirk and other European ports, though there was no threat of enslavement.

${ }^{63}$ Cal. S.P. Dom. 1640, pp. 124 - 5, 448 - 51; Cal. S.P. Dom. 1640 - 1, pp. 559, 578 - 9, 587; Cal. S.P. Dom. $1641-3$, pp. 2, 245, 251. For complaints about Magharibi pirates, see Cal. S.P. Dom. 1640, pp. 448 - 51; Cal. S.P. Dom. 1640 - 1, p. 134.

${ }^{64}$ Andrews, quoting p. 131; for the justifications of ship money, see pp. $130-9$. This was initially argued by

T. W. Fulton in The Sovereignty of the Sea (1911).

${ }^{65}$ For complaints by Pennington from the later 1630s, see Cal. S.P. Dom. 1635, pp. 68, 79, 448, 465, 601;

Cal. S.P. Dom. 1635 - 6, pp. 248, 259, 277, 554; Cal. S.P. Dom. 1637, p. 55; Cal. S.P. Dom. 1637 - 8, p. 246. See also Harding, Evolution of the Sailing Navy, p. 51; and Hebb, Piracy, pp. $222-36$.

${ }^{66}$ William Monson, The Naval Tracts of Sir William Monson, ed. M. Oppenheim (5 vols., 1902 - 13), iii. 232.
} 
any news of pirates or foreign warships, 'which is more than ever he could say before when in those waters' ${ }^{67}$

While Charles certainly had a predilection for building large ships which were unsuited to chasing manoeuvrable corsairs, and his captains sometimes complained that to counter piracy successfully they needed smaller and faster vessels, they also occasionally reported effectively dealing with pirates, and the mere presence of large royal fleets may have made a difference. ${ }^{68}$ There is plenty of persuasive evidence presented by Matar that piracy continued to pose a problem throughout the sixteen-thirties, but at times complaints of piracy grew less clamorous, suggesting that the navy achieved some moderate successes until rebellion in Scotland in 1638 crippled the government's financial capabilities. ${ }^{69}$ If we accept Matar's claim of the genuine threat posed by corsairs, then perhaps seafarers, and more generally coastal communities, would actually have welcomed an increased naval presence, though perhaps not the taxes to fund it.

Finally, Matar draws too large a comparison between royal neglect and parliamentarian policies, though these may have initially promised success. In December 1641 parliament began to raise money for the relief of captives, but the issue continued to be debated throughout the sixteen-forties, and complaints which persisted until 1644, especially from 'the poor Women that daily attend the House, whose Husbands are Captives in Algiers', suggest that these methods were not effective. ${ }^{70}$ When parliament finally, in October 1645 , sent a ship laden with coin intended to ransom English sailors, the voyage was a spectacular disaster. The ship exploded at Gibraltar, and after whatever gold the crew could prevent from being stolen was laden onto another English ship, this too sank in a storm on the way back to England. ${ }^{71}$ Clearly, this was not parliament's fault: but the fact that this took so long to organize suggests that it was not among parliament's top priorities. A second expedition in

\footnotetext{
${ }^{67}$ Cal. S.P. Dom. $1636-7$, p. 151.

${ }^{68}$ For complaints concerning ships, see Cal. S.P. Dom. 1634 - 5, p. 212; N.M.M., JOD/1/1 fo. 17r; Hebb, Piracy, p. 205. On dealing with pirates, see Cal. S.P. Dom. 1637, pp. 340 - 1; Cal. S.P. Dom. 1637 - 8, p. 36; N.M.M., JOD/1/1 fos. 89r, 91r-95r, 103v, 104r-105v.

${ }^{69}$ Matar, Britain and Barbary, pp. 38 - 62, $74-87$.

${ }^{70}$ Quoting C.J., ii. 597; cf. L.J., v. 605; L.J., vi. 19, 440, 501; C.J., iii. 55 - 6. In all quotations, emphasis is original unless otherwise noted.

71 T.N.A.: P.R.O., HCA 13/60, depositions of Edmund Seaman, 15 Jan. 1645[/6], Mathew Grant, 26 March 1646, Thomas Tunnicke, 7 Apr. 1646 and 11 June 1646, Richard Crandley, 11 June 1646; Edmund Cason, $A$ relation of the whole proceedings concerning the redemption of the captives in Algiers and Tunis (1647), pp. 58. Curiously, this was predicted in a royalist newsbook (Mercurius Aulicus, ed. Peter Heylyn and John Birkenhead, 18 - 24 Aug.1644, p. 1129).
} 
1646 was somewhat more successful, freeing 245 captives, fewer than Rainsborough's 1637 expedition. $^{72}$

The increase in both Magharibi and European piracy naturally caused concern within the maritime community as a threat both to individuals and to their livelihood, and the failure of the navy to prevent it may therefore have created a sense of anti-government disillusionment among the maritime community, but it is far from clear whether it prompted a unanimously hostile response to Charles's naval programme. Nor did parliament deliver redress as swiftly or efficiently as Matar claimed, although the initial moves made in 1640-2 probably appeared positive. As with the question of naval neglect, it seems difficult to explain the decisions of seafarers in 1640-2 solely in these terms.

A third interpretation has been suggested by Richard Harding, though this idea has not been fully explored. In a general history of the navy, Harding argued that the 'common seamen largely shared the loyalties of the seamen officers', and that these 'bonds of leadership [were] based upon a common heritage in the maritime community of merchants, shopkeepers, artisans, shipowners, masters and sailors'. More importantly, he contended that:

There had been no sudden revolution in the fleet. Professional tension had been rising during the late $1630 \mathrm{~s}$ and the close relationship between the seamen officers, Trinity House [the corporation of shipmasters], the Thames maritime community, the City merchants and Parliament gave that resentment a political focus.

Here again, the emphasis is upon seafarers' preoccupation with their own profession, and Harding echoed Oppenheim that this 'professional tension' may have been the result of 'years of resentment against the Crown's navy, resulting from delayed pay, [and] poor victuals and clothes'. ${ }^{73}$ Even if the theory of naval 'resentment' is not convincing, the idea that the support for parliament among the maritime community was a reaction to the intrusive policies of Charles I and the result of a 'common heritage' is an appealing one, and fits with the arguments of historians who see Charles's approach to government disturbing the delicate balance of Stuart Britain. ${ }^{74}$ It also implies that the vocational identity of seafarers was critical in determining their reactions to the central government.

\footnotetext{
${ }^{72}$ Cason, pp. 17 - 24; Giles Grene, A declaration in vindication of the honour of the parliament, and of the committee of the navy and customes, against all traducers (1647), pp. $14-15$.

${ }^{73}$ Harding, Evolution of the Sailing Navy, pp. $61-2$.

${ }^{74}$ Especially D. Cressy, 'Conflict, consensus, and the willingness to wink: the erosion of community in Charles I’s England', Huntington Libr. Quarterly, lxi (1998), 131 - 49.
} 
Charles was certainly more deliberate in attempting to exert his 'sovereignty' over the seas surrounding Britain than many of his predecessors. ${ }^{75}$ This was partially a question of circumstances; in the early seventeenth century, following Grotius's Mare Liberum, the question of authority at sea exercised European governors and legal theorists alike. ${ }^{76}$ At the same time, the rise of Dutch maritime power, and specifically in the sixteen-thirties the expansion of the French navy and increasing tensions between France and Britain, made this a practical issue. ${ }^{77}$ Charles's anxiety is evident in his orders to captains that they should 'maintain the King's honour, and the regality of the Narrow Seas, if it should be questioned'. ${ }^{78}$ They were 'to be the more jealous because some pretend to have an interest in the sovereignty of these seas', although when Pennington requested clarification as to who these pretenders were he received only a vague answer. ${ }^{79}$

At the same time Charles sponsored a more developed theoretical justification of his 'sovereignty', culminating in John Selden's famous Mare Clausum, dedicated to Charles and written under 'the auspices of your roused Majesty'. ${ }^{80}$ An English translation of Selden's text did not appear until the sixteen-fifties, but nevertheless these arguments were implemented in Charles's naval policy. ${ }^{81}$ In 1634 a 'Reglement for the Narrow Seas' was published, declaring that 'the seas, commonly called the four English Seas, are more infested nowadays than heretofore by Men of War ... to the denial and impeachment of that Sovereignty ... which his Majesty and Predecessors time out of mind have had', and banning all violence in these

\footnotetext{
${ }^{75}$ The most comprehensive overview, though outdated, is Fulton.

${ }^{76}$ [Hugo Grotius], Mare Liberum (Leiden, 1609); see M. Brito Vieira,'Mare Liberum vs Mare Clausum: Grotius,

Freitas, and Selden's debate on dominion over the seas', Jour. Hist. of Ideas, lxiv (2003), 361 - 77; H. Thornton, 'Hugo Grotius and the freedom of the seas', International Jour. Maritime Hist., xvi (2004), 17 - 38; and H. Thornton, 'John Selden's response to Hugo Grotius: the argument for closed seas', International Jour. Maritime Hist., xviii (2006), 105 - 28. Less notice has been taken of the contribution by the Scottish juror William Welwood (see An abridgement of all sea-lawes (1613) and De dominio maris (161 ); J. D. Alsop, 'William Welwood, Anne of Denmark and the sovereignty of the sea', Scottish Hist. Rev., lix (1980), 171 - 4).

${ }_{77}$ Cal. S.P. Dom. 1631 - 3, pp. 71, 76 - 7, 146 - 7, 170; Cal. S.P. Dom. 1633 - 4, pp. 147, 339; N.M.M., JOD/1/1 fo. 78v; T.N.A.: P.R.O., HCA 13/52 fo. 105r-v; HCA 13/56, deposition of George Cheathem, 28 May 1640; J. Meyer and M. Acerra, Histoire de la marine française: des origines à nos jours (Rennes, 1994), p. 33; J. Bruijn, The Dutch Navy of the 17th and 18th Centuries (Columbia. S.C., 1993). For overviews of early modern naval development, see J. Glete, Navies and Nations:Warships, Navies and State Building in Europe and America, 1500 - 1860 (2 vols., Stockholm, 1993); and J. Glete, Warfare at Sea, 1500 - 1650 : Maritime Conflicts and the Transformation of Europe (2000).

${ }^{78}$ Cal. S.P. Dom. 1633 - 4, p. 117; cf. T.N.A.: P.R.O., SP $16 / 157$ fos. 122v, 137 r.

${ }^{79}$ Cal. S.P. Dom. $1631-3$, pp. 155, 158, 162.

${ }^{80}$ John Selden, Mare Clausum (1635), sig. A2v: 'Maiestatis Tuæ auspiciis excitus'. An earlier manuscript treatise was written, at Charles's request, by Sir John Burough, keeper of the records in the Tower: for a copy, see N.M.M., CAD/D/18; and for Charles's involvement, see N.M.M., REC/3 fo. $268 \mathrm{v}$. An expanded version of Welwood, An abridgement of all sea laws, was also published in 1636.

${ }^{81}$ John Burough, The soveraignty of the British seas (1651); John Selden, Of the dominion or, ownership of the sea, trans. Marchamont Nedham (1652).
} 
seas. ${ }^{82}$ This proclamation also stated that Charles intended that maps delineating these 'English seas' would be 'affixed in the most Publick places of his Chiefest Sea-Towns and Harbours', although it seems that this was never carried out. ${ }^{83}$

Charles's policies had a number of practical implications for the maritime community which may have been intrusive: Charles effectively wanted to expand the pace domini regis beyond the shores of his kingdom to envelop the maritime sphere. ${ }^{84}$ His prohibition of seaborne violence, except that conducted by royal ships, contradicted the custom of reprisal and privateering by which merchants and ship-owners pursued reparations for damage done by pirates or enemies. ${ }^{85}$ There also appears to have been a change in attitude towards seafarers and their vocational culture. Orders issued to naval captains during the sixteentwenties included the proviso 'in all things not $\mathrm{p}[\operatorname{ar}]$ ticularly here directed $\mathrm{y}[\mathrm{o}] \mathrm{u}$ are to follow the knowne orders of the Sea', a phrase which had disappeared by 1629 . Similarly, references to religious services 'according to the use of the Church of England and of the sea' were replaced by just the liturgy of the Church of England. ${ }^{86}$ It seems that Charles was attempting to integrate seafarers and the semi-autonomous space of the ship more firmly into his vision of the British state, though these orders applied only to naval vessels. ${ }^{87}$

In other, more concrete ways, the royal government interfered in maritime affairs. The king pursued a legal course to deny coastal towns traditional rights and perquisites of admiralty, in order to assert his own jurisdiction. ${ }^{88}$ Charles also ordered that all British ships should bring their goods into British ports, because when they unloaded at foreign ports he was deprived of customs revenues; the master and merchant of one ship stopped by Captain Plumleigh were reported to 'storme much at the stay and refuse utterly to pay any Custome or composition as a thing unheard of till this time'. ${ }^{89}$ It is revealing that this was criticized as an innovation, and opposition to it, and to other forms of maritime authority, continued in

\footnotetext{
${ }^{82}$ Cal. S.P. Dom. $1634-5$, mentions an undated copy, p. 382; this quotation is from a later transcript giving the original date as 1634 in T.N.A.: P.R.O., ADM 7/729 pp. 95 - 101, at pp. $95-6$.

${ }^{83}$ T.N.A.: P.R.O., ADM 7/739 p. 98; the earl of Lindsey, admiral in 1635, requested a clarification of these limits (Cal. S.P. Dom. 1635, p. 71).

${ }^{84}$ This phrase appears in the instructions of the earl of Northumberland in 1636 (N.M.M., LEC/5 fo. 4v).

${ }^{85}$ For a discussion of privateering and piracy, see Pirates? The Politics of Plunder, $1550-1650$, ed. C. Jowitt (Basingstoke, 2007); D. J. Starkey, 'Voluntaries and sea robbers: a review of the academic literature on privateering, corsairing, buccaneering and piracy', Mariner's Mirror, xcvii (2011), 127 - 47.

${ }^{86}$ T.N.A.: P.R.O., SP 16/157 fos. 12r, 17r, 18r, 103v-105v, 121r-123v.

${ }^{87}$ On ship space and religious practice, see Patarino; and S. Parsons, 'Religion and the sea in early modern England, c. 1580 - 1640' (unpublished University of Exeter Ph.D. thesis, 2010).

${ }^{88}$ T.N.A.: P.R.O., SP 16/264 fo. 55r; D. D. Hebb, 'Profiting from misfortune: corruption and the admiralty under the early Stuarts', in Politics, Religion and Popularity in Early Stuart Britain: Essays in Honour of Conrad Russell, ed. T. Cogswell, R. Cust and P. Lake (Cambridge, 2002), pp. 103 - 23, at p. 123.

${ }^{89}$ Quoting T.N.A.: P.R.O., SP 16/199 fo. 4r; cf. N.M.M., JOD/1/1 fo. 32r; T.N.A.: P.R.O., SP 16/228 fos. 26r, $47 \mathrm{r}$.
} 
following years. ${ }^{90}$ These incidents of isolated protest do not necessarily add up to a rise in 'professional tension', a 'resentment' given 'political focus' during the sixteen-thirties: there were no major riots in that decade as there had been in the sixteen-twenties and would be again in the sixteen-forties. Yet they do hint that seafarers were brought more forcefully into contact with the state during Charles's personal rule, usually through the navy, and in ways not exactly calculated to engender a positive response. It could have been precisely this increased contact which drew seafarers into national debates. As with the question of naval neglect, or the impact of piracy, there is insufficient evidence to regard this as the decisive factor in July 1642, but it may, like them, have contributed towards the outbreak of civil war.

Some seafarers perhaps disliked the Stuart regime because of mistreatment during naval service, and preferred parliament because they promised better conditions and pay; some probably felt that Charles had not protected British trade from piracy as much as he should have done. Others could have resented the government's increased interference in maritime affairs, which in some ways challenged the vocational culture and independence of seafarers.Yet none of these theories, based on a negative attitude towards Charles and his government, and solely dealing with the maritime sphere, adequately explains the apparently enthusiastic support for parliament within the fleet. We must integrate these arguments with a more careful survey of the available evidence, paying particular attention to the wider maritime community rather than just the navy. It is instructive, in this case, to compare the involvement of seafarers in popular protests and petitioning during the sixteen-twenties and sixteen-forties, as these provide the clearest evidence concerning the attitudes of the maritime community. ${ }^{91}$

The later sixteen-twenties were a time of political turmoil in London. Parliament and the king were repeatedly at loggerheads, there were frequently large crowds in Westminster, and in the east of the city sailors gathered to protest and riot in complaint over their treatment and pay. ${ }^{92}$ Yet there are a few important characteristics of these riots which must be borne in

\footnotetext{
${ }^{90}$ Cal. S.P. Dom. 1631 - 3, pp. 143, 148, 158; N.M.M., JOD/1/1 fos. 57r-58r, 60r, 88v. E.g., there are continued reports of English ships refusing to lower their topsails and flags in the customary gesture of deference to royal ships (N.M.M., JOD/1/1 fos. 3r, 28r, 34r-v, 35r, 37r, 44r, 52v, 56v, 60v; Cal. S.P. Dom. 1635, p. 353 ).

${ }^{91}$ For analyses of the outbreak of civil war using these kinds of evidence, see esp. the work of John Walter: Understanding Popular Violence in the English Revolution (Cambridge, 1999); 'Confessional politics in precivil war Essex: prayer books, profanations, and petitions', Historical Jour., xliv (2001), 677 - 701; 'Popular iconoclasm and the politics of the parish in eastern England, 1640 - 2 ', Historical Jour., xlvii (2004), 261 - 90; Crowds and Popular Politics in Early Modern England (Manchester, 2006); "Affronts and insolencies": the voices of Radwinter and popular opposition to Laudianism', Eng. Hist. Rev., cxxii (2007), 35 - 60.

${ }^{92}$ For the politics of the later 1620s, see C. Russell, Parliaments and English Politics 1621 - 9 (Oxford, 1979),
} 
mind. Significantly, they seem to have been isolated from similar protests elsewhere, and comprised mostly disgruntled seamen, and perhaps their families, as well as some soldiers; much protest took place aboard ship. ${ }^{93}$ Moreover, the targets of larger, London-based protests were clearly the naval administrators. In October 1626, an order was given to restrain the 'disorderly repair of mariners and soldiers to London' to demand pay, and when they confronted the duke of Buckingham, then admiral, he initially made promises, but afterwards forbade them to come to court. ${ }^{94}$ In late 1627 and early 1628 , the navy commissioners complained that mariners 'doe much trouble, and interrupt us at $\mathrm{o}[\mathrm{u}] \mathrm{r}$ meetings', and that unless they were paid 'nothing can bee expected but a sudden mutinie'; the government consequently threatened the sailors with the city's militia. ${ }^{95}$

In addition, the demands of the sailors clearly concern only immediate material grievances: within the navy, the complaints are almost entirely about the lack of pay or supplies, which are supported by similar criticisms from naval officers. ${ }^{96}$ Mariners also complained about the general situation of trade. In March 1627, a petition 'of all the mariners and poore Seafaring men, within the Ports and Sea coast Townes, betweene London and Barwick' complained of the 'many misseries w[hi]ch the pet[itione]rs groane under', and requested the king to 'curb the over-daring Enemie'. ${ }^{97}$ Similar complaints, again focused on wages and the conditions of trade, were articulated in a petition to parliament in $1628 .{ }^{98} \mathrm{We}$ should, though, be careful about complaints concerning the state of trade: these were perennial and perhaps represent a similar sensitivity to subsistence levels to that found in agrarian communities. ${ }^{99}$

chs. 4 - 7; T. Cogswell, 'Foreign policy and parliament: the case of La Rochelle, 1625 - 6', Eng. Hist. Rev., xcix

(1984), 241 - 67; T. Cogswell, 'Prelude to Ré: the Anglo-French struggle over La Rochelle, 1624 - 7', History, lxxi (1986), 1 - 21; R. Cust, The Forced Loan and English Politics, 1626 - 8 (Oxford, 1987); T. Cogswell, 'A low road to extinction? Supply and redress of grievances in the parliaments of the 1620s', Historical Jour., xxxiii (1990), 283 - 303; R. Cust, Charles I: a Political Life (Harlow, 2007), ch. 5. For events in London in particular, see V. Pearl, London and the Outbreak of the Puritan Revolution: City Government and National Politics, 1625 - 43 (1961), pp. $76-9$.

${ }^{93}$ Cal. S.P. Dom. 1625 - 6, pp. 304, 324, 359, 366, 379, 423, 449, 460; Cal. S.P. Dom. 1627 - 8, pp. 173, 513; Cal. S.P. Dom. $1629-31$, p. 64.

${ }^{94}$ T.N.A.: P.R.O., SP 16/38 fo. 33v; Charles I, By the king. A proclamation for the restraint of the disorderly repaire of mariners and souldiers, unto the Kings Court, or Citie of London (7 Oct. 1626).

${ }^{95}$ T.N.A.: P.R.O., SP 16/91 fos. 1r, 126r; Charles I, By the king. A proclamation for the repressing of disorders of

Marriners (7 Feb. 1627[/8]).

${ }^{96}$ Cal. S.P. Dom. 1625 - 6, pp. 239, 257, 304, 359, 366, 379 - 80, 423; Cal. S.P. Dom. 1627 - 8, pp. 192, 320, 465 - 6, 478; Cal. S.P. Dom. 1628 - 9, p. 357; Cal. S.P. Dom. 1629 - 31, pp. 1, 59, 64, 96, 328, 338, 538.

${ }^{97}$ T.N.A.: P.R.O., SP $16 / 58$ fo. 9 r.

${ }^{98}$ T.N.A.: P.R.O., SP $16 / 102$ fo. 141 r.

${ }^{99}$ J. Walter and K. Wrightson, 'Dearth and the social order in early modern England', Past \& Present, lxxi (1976), 22 - 42; P. Slack, 'Dearth and social policy in early modern England', Social History of Medicine, v 
It is therefore appropriate to see this spectrum of protest and complaint, ranging from collective mutinies aboard individual ships to large-scale crowd actions in London, as emerging from the same grievances, and influenced by a tradition of labour protest by which sailors sometimes negotiated the conditions of their employment. It is in the same period, according to Kenneth Andrews, that mutiny was increasing among seafarers, due to the expansion in trade and consequently the demand for seafaring labour. ${ }^{100}$ Certainly, there was anxiety in the government over the tactics sailors used to protest; writing signatures in a circle, and the 'common answer of One and All', by which seafarers avoided any individual being singled out as ringleader, were prohibited by the admiralty court in $1631 .{ }^{101}$ It therefore seems reasonable to locate the protests of the sixteen-twenties within this tradition of mutiny, as they were confined to the maritime community, and provoked by issues arising from naval employment and the decline of trade during wartime.

It is difficult to see the protests of the early sixteen-forties in the same way, though the actions of individual seafarers may still have been shaped by these conventions of labour protest. In some popular political actions, admittedly, the distinct concerns of the community are apparent. Early in May 1641, some thousand sailors rioted near the Tower, protesting against the closing of ports; they pulled down some houses before the militia drove them off, killing three. ${ }^{102}$ The crowd reportedly 'got the Flag of a ship' before they marched on the Tower, implying an element of deliberate political theatre and perhaps the sense that this was a specific seafaring matter, though their choice of target, the principal fortress of the country rather than the offices of the naval administration, is significant. ${ }^{103}$ There is only one mention of 'insolencies and misdemeano[u]rs' among sailors aboard a naval ship, in July 1641, which appears to be over lack of money. ${ }^{104}$ Disorder was more widespread, though: in May 1642 Trinity House passed an 'Act touching disordered Seamen', describing 'daily complaints of the disorders of Seamen and of theire want of care, and honestie, in not attendinge and lyeing aboard theire shipps aswell here in the River before they goe forth as alsoe after they come home', and authorizing masters to fine mariners who were tardy after being hired. ${ }^{105}$

(1992), 1 - 17; S. Hindle, 'Exclusion crises: poverty, migration and parochial responsibility in English rural communities, c. 1560 - 1660', Rural Hist., vii (1996), 125 - 49; S. Hindle, 'Dearth and the English revolution: the harvest crisis of $1647-50$ ', Econ. Hist. Rev., lxi (2008), $64-98$.

100 Andrews, ch. 3.

101 Andrews, pp. 63 - 4, citing T.N.A.: P.R.O., HCA 3/33 fos. $514-15$.

102 L.J., iv. 244 - 5; British Library, Harleian MS. 164 fos. 207v, 209r; Harleian MS. 6424 fo. 65v. Lindley, p. 25 describes these as 'bawdy houses', but there is no mention of this in the parliamentary journals or diaries.

103 C.J., ii. 143 .

104 T.N.A.: P.R.O., SP $16 / 482$ fo. 21 r.

105 T.N.A.: P.R.O., HCA 30/853 fo. 494r. 
However, during the sixteen-forties sailors joined riots which involved a wide range of society, especially apprentices and other young people. The targets of these protests were not the naval administration, but political and religious sites: one of the largest riots, in May 1640 , focused on Lambeth Palace, seat of the archbishop of Canterbury. ${ }^{106}$ Following this riot, the privy council wrote to both Watermen's Hall and Trinity House. The council complained that 'there were diu[e]rs idle \& lewd p[er]sons transported to \& from Ratcliff, Blackwall, [Rotherhithe], wapping \& other p[ar]ts thereab[ou]ts, whereby [th]e s[ai]d disorderly \& rebellious assemblies were much increased', and ordered that no 'idle or suspected p[er]sons' should be given passage on boats at night. ${ }^{107}$ The mention of these specific hamlets, where seafarers were numerous, and the inclusion of Trinity House in this order, suggests a large number of mariners were involved in the riot. According to one observer, in the winter of 1641 seamen and watermen again 'came by water before Whitehall' in barges, at the same time as large crowds of apprentices gathered outside Westminster. ${ }^{108}$

Clearly, the maritime community were not interested only in the conditions of the shipping industry: rather, issues specific to seafaring were popularly and publicly linked to the wider crisis in Britain. In none of the public statements purporting to come from seafarers during these years is there any mention of naval mistreatment and neglect, and in most, anxiety about maritime employment was associated with the political debates of the day, in particular the clash of religious identities which had begun to tear Britain apart. A petition submitted to the House of Lords by 'young Men, Apprentices and Seamen' on 26 January 1642 , and subsequently printed, complained of suffering 'unsupportable pressures' because 'Trading is extraordinarily decayed', which suggests a preoccupation with material concerns. However, the petition blamed this on 'that abominable Rebellion of the bloody Papists' in Ireland, which had begun the previous October, and requested that 'the Kingdome at home may be speedily put into such a posture of Warre and defence, as may enable them against all forreigne Invasion, and domestique plots, and conspiracies of Papists, and their adherents'. ${ }^{109}$

\footnotetext{
${ }^{106}$ For these riots, see Lindley, pp. 4, 8; Cressy, England on Edge, pp. 110 - 26.

107 T.N.A.: P.R.O., SP 16/453 fos. 192 r.

108 J. Bramston, The Autobiography of Sir John Bramston, K.B., ed. T.W. Bramston (1845), p. 82; cited in Cressy, England on Edge, p. 386.

${ }^{109}$ To the right honourable the House of Lords now assembled in parliament. The humble petition of the young men, apprentices and sea-men, in and about the citie of London (1642); L.J., iv. 544, 549.The original of the Lords petition does not survive in the relevant volumes of Lords papers for the period (Parliamentary Archives, $\mathrm{HL} / \mathrm{PO} / \mathrm{JO} / 10 / 1 / 114 ; \mathrm{HL} / \mathrm{PO} / \mathrm{JO} / 10 / 1 / 140$; and $\mathrm{HL} / \mathrm{PO} / \mathrm{JO} / 10 / 4 / 6)$. On the impact of 'popish plots', see K. J. Lindley, 'The impact of the 1641 rebellion upon England and Wales, 1641 - 5', Irish Hist. Studies, xviii (1972), 143 - 76; R. von Friedeburg, 'The continental counter-Reformation and the plausibility of the popish plots,
} 
On 14 January, the House of Commons had appointed a committee to consider 'putting the Kingdom into a Posture of Defence', suggesting that the drafters of the petition were well informed about attitudes in parliament. ${ }^{110}$ As it was Warwick who introduced this petition to the Lords, it could suggest that some leading figures in the maritime community were already working closely with him. ${ }^{111}$ A very similar petition from 'the marriners and sea-men, inhabitants in, and about the ports of London', supposedly 'subscribed by many thousands', had been submitted to the House of Commons earlier in the month. ${ }^{112}$ Likewise, an anonymous Generall remonstrance or declaration of the sea-men, dated 31 January, described its subjects as 'wee of the true Protestant Religion', and, while addressing Charles in respectful terms, primarily requested letters of marque against the Irish. ${ }^{113}$ These petitions, and possibly also the Remonstrance, suggest that a number of mariners were aware of, concerned about, and involved in political developments on a national scale.

It is no coincidence that these documents originated in January 1642, a particularly fraught month during which Charles, having failed in his attempt to arrest five members of the Commons and one peer, fled London. ${ }^{114}$ The petition to the Commons was in fact submitted to a committee of the House sitting at the Guildhall in the midst of this crisis. ${ }^{115}$ Some 2,000 sailors took part in the procession which triumphantly returned these five to Westminster later in the month, and the longest discussion of seafarers' political activity is found in The seamans protestation concerning their ebbing and flowing to . . Westminster, a justification of these actions. ${ }^{116}$ Some historians, usually because of an assumption that sailors were largely illiterate, have been reluctant to see this text as genuinely representative of the maritime community. Powell claimed that it had been written by 'a far abler hand than that of

1638 - 42', in England's Wars of Religion, Revisited, ed. C. W. A. Prior and G. Burgess (Farnham, 2011), pp. $49-73$.

${ }^{110}$ C.J., ii. 379. I am grateful to David Smith for pointing this out.

111 L.J., iv. 544. On the organization of petitions during this period, see Pearl, pp. 228 - 35; Walter, 'Confessional politics in pre-civil war Essex', p. 701; and D. Zaret, 'Petitions and the "invention" of public opinion in the English revolution', American Jour. Sociology, ci (1996), 1497 - 1555.

${ }^{112}$ To the honourable, the knights, citizens, and burgesses of the Commons, now assembled in parliament. The humble petition of the marriners and sea-men, inhabitants in, and about the ports of London, and the river of Thames (1642); cf. Anon, Diurnall occurrences in Parliament (2 - 10 Jan. 1641[/2]), p. 5.

${ }^{113}$ Anon., The generall remonstrance or declaration of the sea-men, which inhabit in London and thereabouts (1642).

${ }_{114}$ A. Fletcher, The Outbreak of the English Civil War (1981), ch. 5; Cressy, England on Edge, ch. 18.

115 C.J., ii. 370.

${ }^{116}$ Anon., The seamans protestation concerning their ebbing and flowing to and from the Parliament house at Westminster: upon Tuesday the 11 day of January, 1642 (London and Edinburgh, 1642); C.J., ii. 370; Cal. S.P. Dom. $1641-3$, p. 252. 
an ordinary seaman', and more recently Brian Lavery declared that it 'was far too literate and politically sophisticated to be the work of the average seaman' ${ }^{117}$

The fact that it was published on Warwick's order may indeed suggest that it was a piece of parliamentarian propaganda. However, it could still have been produced by a seafarer, perhaps one of the Trinity House clique of shipmasters who were to take naval commands during the war, some of whom, for example William Batten, had previously published complex navigational texts. ${ }^{118}$ These were presumably not what Powell and Lavery had in mind for 'ordinary' or 'average' sailors, but they were nevertheless influential members of the maritime community, and literacy among seafarers appears to have been higher than previously thought. ${ }^{119}$ The pamphlet, then, should not be dismissed so lightly.

The seamans protestation suggests a great deal of sensitivity to both the impact of seafarers' involvement in political demonstrations, and the interpretations likely to be placed upon this. It attempts to defend seafarers from potential accusations of meddling in affairs beyond their station, or even of rebellion. The pamphlet opens by acknowledging that 'Ovr appearance above the Bridge, being a passage the Histories of England cannot exemplifie, may cause our good intents and well-meaning, in the various apprehensions of most men to be misconstrued'. The author maintained that the sailors were not called by parliament, but came 'of our own free voluntarie disposition ... as well to protect White-hall, had his Majestie been there, as the Parliament house'. ${ }^{120}$ The main concerns of the pamphlet were characterized in religious terms; enemies were defined as 'Papists', and seafaring described as a defence of Protestantism, the author adding that 'although we have no Churches, we say our prayers as well as you, the same God you have at shore is ours at sea'. ${ }^{121}$ The Protestation concluded with an oath supposedly sworn by mariners, to defend religion 'as it was established in the dayes of Queen Elisabeth', to protect the king and parliament, and 'from my heart to abhor all Poperie'. ${ }^{122}$ This was, as John Walter noted, closely modelled on another 'Protestation oath' sworn throughout London on the orders of parliament. ${ }^{123}$ In the

\footnotetext{
117 Powell, p. 3; Lavery, p. 63. Powell does not mention the published version but cites G. Penn, Memorials of the Professional Life and Times of Sir William Penn ... from 1644 to 1670 (2 vols., 1838), ii. 17. John Walter, however, takes it seriously (Walter, Understanding Popular Politics, pp. 317 - 18).

${ }^{118} \mathrm{~W}[$ [illiam] B[atten] and J[ohn] T[app], A most plaine and easie way for the finding of the sunnes amplitude and azimuth (1630). Batten was also to publish political pamphlets in 1648 (William Batten, The sea-mans dial, or, the mariners card (1648); William Batten, A declaration of William Batten, late vice-admiral for the parliament (1648)).

${ }^{119}$ Literacy among seafarers is discussed in Blakemore, pp. 41 - 3; see also Patarino, pp. 176 - 81.

${ }^{120}$ Anon., The seamans protestation, sig. A2r.

${ }^{121}$ Anon., The seamans protestation, sig. A2v-3r.

${ }^{122}$ Anon., The seamans protestation, sig. A3v.

${ }^{123}$ Walter, Understanding Popular Violence, p. 317.
} 
eastern suburbs of Limehouse, Ratcliff, Poplar and Blackwall, 1,688 men swore this oath, and only sixty-six refused, although a further 510 in Limehouse and Ratcliff were listed as 'at sea'. ${ }^{124}$ This evidence indicates, like the petitions and Generall remonstrance of the same month, that the activities of seafarers were not focused upon some internal dispute about the navy, nor a reaction solely to concerns over trade, but were part of the wider crisis gripping Britain.

In 1640-2, then, large numbers of seafarers participated in popular political agitation which appears to be markedly different in composition, targets and purpose to the naval riots of the sixteen-twenties. It might be argued that it was only different in appearance, that the underlying resistance was essentially similar, but that seafarers protested in the language of the moment - allegations of corruption and inefficiency in the sixteen-twenties, religious and political crisis in the sixteen-forties. Even this would suppose a political awareness rarely accorded to the maritime community by historians. Yet the further evidence for political and religious disputes within the community at a personal level belies this, emphasizing the extent to which these issues mattered to individuals.

Much of this evidence comes from the parish of Stepney, where there was the greatest concentration of mariners in London, and which may have been unique; no other Thamesside parish has generated so much evidence of open debate and argument. Certainly religious feelings ran high in the parish in the early sixteen-forties. It would seem that William Stampe, previously Stepney's schoolmaster and appointed vicar in 1641 , was unpopular with some of his parishioners, particularly because of his sympathy for the king and the Book of Common Prayer. ${ }^{125}$ Indeed, the dislike for Stampe and the official liturgy, and the discontent with royal government, were very closely linked in the parish. At Easter 1642, John Baskett allegedly said

\footnotetext{
${ }^{124}$ Parliamentary Archives, HL/PO/JO/10/1/99 fos. 208r- 19r, 238r-44r, 249r-60r. On the Protestation, see D. Cressy, 'The Protestation protested, 1641 and 1642', Historical Jour., xlv (2002), 251 - 79, at p. 268; see also Fletcher, pp. 77 - 8; Walter, Understanding Popular Politics, pp. 292 - 6; E. Vallance, 'Preaching to the converted: religious justifications for the English civil war', Huntington Libr. Quarterly, lxv (2002), 395 - 416, at pp. 402 - 3; E. Vallance, Revolutionary England and the National Covenant: State Oaths, Protestantism and the Political Nation, 1533 - 1682 (Woodbridge, 2005), pp. 512 - 13; and M. Braddick, 'Prayer Book and Protestation: anti-popery, anti-puritanism and the outbreak of the English civil war', in Prior and Burgess, pp. $125-45$.

${ }^{125}$ For Stampe, see J. T. Peacey, 'Stampe, William (b. 1610/11, d. in or after 1654)', O.D.N.B. <http:// www.oxforddnb.com/view/article/26226> [accessed 13 Feb. 2013].
} 
that hee did not care for the kinge \& that hee was as good a man as the kinge w[i]th many other wild speeches both ag[ain]st Mr Stamp Vicar \& . . ag[ain]st the booke of Com[m]on prayer sayinge [tha]t all [tha]t heard \& read it were damned. ${ }^{126}$

Rachel Weaburne, also from Stepney, was presented to the Middlesex bench in July 'for sayinge that Mr Edgworth Curate of Stepney p[ar]ish was a damnd dogg \& [tha]t shee would rather goe to heare a Cart wheele creake and a dogg barke than to heare him preach and other ill language', while Rachell Pollister was accused in the same month of 'sayinge that the kinge was a papist and a ranke papist \& Cronicled for one'. ${ }^{127}$ These disputes also involved at least some members of the seafaring community. On 3 March 1642, William Berry, a mariner of Wapping, was accused by Edward Allen, another seaman from Suffolk, of 'villifying of the King in saying that he cared not a fart for the Kinge'. ${ }^{128}$ Clearly vocational ties could clash with other social loyalties.

In the summer of 1642, as events leading to war accelerated, Stampe got into trouble with parliament. ${ }^{129}$ On 25 July, he was accused of violently interrupting the recruitment of volunteers for parliament's army. ${ }^{130}$ Not long after this Stampe and his brother were accused of inciting a group of sailors to disturb a sermon at the church. ${ }^{131}$ This might simply be playing on the stereotype of unruly mariners, but it could also suggest that there were seafarers committed to the traditional church establishment and opposed to parliament's religious reforms, as well as those who supported them. Stepney had some inhabitants who were as outspoken against parliament as others were against the king: Sara Linge, a widow, was accused on 2 August of 'speakinge dangerous words . . . saying, If some of her neighbors would joyne with her, she would cutt the throats of a thousand Roundheads \& Brownists', insults applied to parliament's supporters. ${ }^{132}$

This division in the parish seems to have existed at the very least from the start of 1642, at about the same time when the seamen's petitions, Remonstrance and Protestation were published. An undated printed petition to the House of Commons from Stepney and the surrounding parishes discussed the tensions that were already bubbling. It does not appear in

\footnotetext{
126 London Metropolitan Archives (hereafter L.M.A.), MJ/SR/0915/71. I am grateful to Lloyd Bowen for assistance with the evidence from Stepney.

${ }^{127}$ L.M.A., MJ/SR/0913/8, MJ/SR/0915/70; cf. MJ/SR/0930/104, a similar incident in 1643.

${ }^{128}$ L.M.A., MJ/SR/0906/3.

${ }^{129}$ Peacey.

${ }^{130}$ C.J., ii. 690; L.M.A., MJ/SR/913/242. Oxford, Bodleian Library, Tanner MS. 62 fos 211r-12v.

${ }^{131}$ Peacey; C.J., ii. 695, 703, 729.

132 L.M.A., MJ/SR 0913/154; cf. MJ/SR/909/62 .
} 
the Commons Journal, but given its reference to 'Mr. Pym, and the other foure' (that is, the five members of the Commons whom Charles attempted to arrest) this most likely also dates from January. ${ }^{133}$ Indeed, this petition was printed by William Larner of Eastcheap, who also printed a variant of the 26 January petition to the Lords discussed earlier, as well as other petitions and religious texts at about the same time, which may indicate that these were the work of the same, or connected, people. ${ }^{134}$

The Stepney petition opened by stating that the Thames parishes were left vulnerable because 'a great part of the Inhabitants . . . are Mariners, and other Persons belonging to Navigation, who are often at Sea'. Its main thrust was an accusation against the garrison of the Tower, 'lately put into the same', of being 'many of them Alehouse keepers, and most of them, of loose Conversations', while 'the Trained Souldiers of the Hamlets, who watch in the Tower, are confined unto strait places'. The petitioners then claimed that

Divers words ... have been spoken, by sundry Persons ... tending to the disuniting of the two Kingdomes of England and Scotland, to the defamation of divers Members of this honourable House, and intimating some bloody designe in hand, against the well affected of the Kingdome, under the names of Puritans and Brownists.

The principal culprit was Richard Cray, a constable of Stepney and new warder of the Tower, who had 'endeavoured to raise men in Armes, to keepe those whom he calls Puritans and Brownists, from coming to Church, and hath with many others, his partakers, greatly opposed, the two worthy Preachers at Stepney, Mr. Burroughes, and Mr. Greenhill', who had been newly appointed by parliament. ${ }^{135}$ Cray was indeed an 'Alehouse keeper', who was bound for good behaviour on 21 January, 'beeing by the house of Commons judged not fitt to keepe a victualling house', and for 'some scandalous speeches . . . against the said howse'. ${ }^{136}$ The petitioners clearly felt threatened by Cray and his comrades in the Tower, seeing it as a

\footnotetext{
${ }^{133}$ To the honourable the knights, citizens and burgesses of the House of Commons in parliament assembled. The humble petition of the inhabitants, of the parishes of Stepney, Shoreditch, VVhitechappell, and Algate, the Chappelry of Wapping, the precinct of St Katherins, and the parish of St Peter Advincula, adjacent to the Tower, and without the liberties of London (1642).

${ }^{134}$ Larner's copy of the 26 Jan. petition was printed with the title To the right honourable House of Peeres ... . (1642). Other publications of his include To the honovrable the Hovse of Commons assembled in parliament. The humble petition of many thousand poore people, in and about the citie of London (31 Jan. 1642); and Certaine observations vpon Hosea (1642), which was printed 'at the Bible in Little-East-Cheap'; cf. D. Como, 'Secret printing, the crisis of 1640, and the origins of civil war radicalism', Past \& Present, cxcvi (2007), 37 82 , at p. 38.

135 R. L. Greaves, 'Greenhill, William (1597/8 - 1671$)$ '; $\quad$ O.D.N.B. <http://www.oxforddnb.com/view/article/11429>; and T. Webster, 'Burroughes, Jeremiah (bap. 1601?, d. 1646)', O.D.N.B. <http://www.oxforddnb.com/ view/article/4106> [both accessed 13 Feb. 2013].

${ }^{136}$ L.M.A., MJ/SR 0905/118; cf. MJ/SB/B/0001, bk. 9, p. 39, where Cray was cited for 'abusinge' witnesses.
} 
particular local manifestation of the national problem, and requested permission to 'put themselves into a Posture of defence', again employing parliament's own language.

Some of the other 'sundry Persons' were named, and their 'words' recorded, in a schedule attached to the petition. John Walter of Limehouse was accused of 'many rayling speeches, calling divers people of honest report, a company of damned Puritan-whores and rogues ... [saying] he hoped ere long, to see all their throates cut, or they hang'd, as those are in Ireland'. A writ appears in the Middlesex assize records against Walter for the same words. ${ }^{137}$ The existence of a petition specifically naming individual parishioners and hinting at threats of violence, and the bandying about of insulting religious labels, in addition to the other evidence for religious disputes in Stepney, suggest a very public contest over the future of the parish which was defined in terms of the major religious and other national issues then being debated across the country. Nor was this wholly limited to Stepney: in St. Olave's, Southwark, another parish with a high proportion of mariners, some of the parishioners disturbed the vicar's administration of the sacrament during $1641 .{ }^{138}$ It is unlikely that the seafarers, maritime tradesmen and their families resident in these parishes would have been wholly ignorant of these disputes. Some were definitely involved, and others were active in different ways that suggest religious conviction. For example, the Commons Journal records in August 1642 that 'Mariners upon the River Thames' were lending money 'for the Affairs of Ireland'. ${ }^{139}$

Contentious debate on national issues also appears to have penetrated the royal fleet; indeed, to have done so quite some time before it broke out in Stepney. Thomas Cooke, a boatswain from Chatham, was accused of saying on 25 April 1641:

that King Charles was a Tyrant in demanding ship-monies, \& that in England kings had beene deposed and murdered for lesse matters alleadging further, for iustifing of his speeches, [th]e deposing of King Richard the second of England, \& Jehu's killing of Jehoram, \& [th]e Netherlanders falling off from the king of Spaine.

The corporal of the Guardland, William Toomes, was likewise accused of saying, on 20 August in the captain's cabin, that '[th]e Spanish \& French kings were forbidden by [th]e Pope to aide [th]e Scotts, because now there were great hopes [tha]t king Charles would proue a Romane Catholicke'. Both had apparently said, on board a different ship on 15 June,

\footnotetext{
${ }^{137}$ LM.A., MJ/SR/904/72; cf. Cressy, England on Edge, p. 245.

${ }^{138}$ Cressy, 'The Protestation protested', p. 253.

${ }^{139}$ C.J., ii. 709.
} 
that the king ought to settle peace with the Scots, because a number of counties 'would $\mathrm{w}[\mathrm{i}]$ thstand pressing of souldiers'.Their accusers, three surgeons and a clerk from Rochester, stated that:

The continual disc[ou]rse of theise two men ... is, touching his M[ajes]tie \& State-affaires, euen publickly, before common seamen, still censuring what is done by his M[ajes]tie \& [th]e State; \& speaking most athistically against Bishops, \& all church-men, \& church-discipline, \& Ecclesiasticall Courts . . . [if one of them] heares of any thing disastrous to [th]e king or state ... he relates it againe in a gesture of reioycing. ${ }^{140}$

The surgeons also complained that they 'haue been thre[ate]ned to be throwne ouer-board, least they call theise . . . in question $\&$ haue beene disc[ou]rteously used by [th]e Capt[ain], for this very cause, \& . . Cooke would still boldly say, [tha]t [th]e Capt[ain] would beare him out in all things'. ${ }^{141}$ Indeed, both Captain Fogge and the gunner of the Guardland were accused of attempting to keep the witnesses quiet 'by promises \& threatninges', stating that 'they had spoken noething but what became honest men to speak'. ${ }^{142}$ Also intriguing is the mention of 'those pamphletts scattered abroad against the king by [th]e Scots, \& printed beyond sea', the contents of which Toomes endorsed as true, 'adding thereuntoe [tha]t [th]e Scotts rebelled, because the king intended to bring in Arminianisme \& Popery amongst them'. ${ }^{143}$

Toomes, Cooke and the gunner all claimed that they "never thought or said such thinge or thinges', though that is not a surprising response to a charge of treason. ${ }^{144}$ These scant and contested accusations thus cannot be taken to indicate wholesale disaffection among the fleet and the maritime community, and there are no similar reports for later in the sixteen-forties, for example the reaction in the fleet to the Irish rebellion which seems to have flared passions so dramatically in Stepney. Nevertheless, the very existence of such accusations, and their detail, is compelling evidence for sensitivity to the religious and political issues then causing divisions across Britain, and hint at the existence of animated, informed and sustained debate among sailors, from 'common seamen' to ships' captains. In

\footnotetext{
140 T.N.A.: P.R.O., HCA $1 / 7$ fos. 25r-v (author's emphasis); see also the depositions in HCA 1/50 fos. 92r-98v. Andrews was certainly aware of the accusations but, surprisingly, consigned them to a footnote with no real discussion (Andrews, p. 81, n. 70).

141 T.N.A.: P.R.O., HCA $1 / 7$ fo. $25 \mathrm{v}$.

142 T.N.A.: P.R.O., HCA $1 / 50$ fo. $96 \mathrm{v}$.

143 T.N.A.: P.R.O., HCA $1 / 7$ fo. $25 \mathrm{v}$.

${ }^{144}$ Quoting T.N.A.: P.R.O., HCA $1 / 50$ fo. $93 \mathrm{v}$; cf. fos. $92 \mathrm{r}-93 \mathrm{v}, 97 \mathrm{v}-98 \mathrm{v}$.
} 
the light of this evidence, it is impossible to treat all seafarers as politically ignorant and motivated only by economic conditions.

In particular, religion appears as the major motivating factor in mobilizing a significant proportion of the maritime community both to support and to oppose parliament, with a particular crisis occurring in January 1642, a response to Charles's attempted arrest of five members of the Commons and one lord, and internal disputes within the Thames parishes, resulting from panic over the Irish rebellion. Though John Adamson has recently criticized the idea of the civil wars as England's 'wars of religion', a phrase first employed by John Morrill, and though the concern over other political issues such as illegal taxation is also apparent, religion is the consistent thread which links together the dispute in Stepney, the rioting throughout 1640-2 and seemingly the disquiet in the fleet. ${ }^{145}$ That is not to suggest that there was a coherent religious underground, uniting all of those seafarers dissatisfied with the religious situation in Britain and seeking a different church establishment. Rather, as a number of historians have recently concluded, of all the diverse factors which pushed people into civil war, it appears that religion - or fear and paranoia associated with religious identities - was the most widespread and the most emotive. ${ }^{146}$

What emerges most powerfully from this evidence is that seafarers, though undeniably (and quite expectedly) interested in issues of maritime employment and naval policy, did not focus upon these questions to the exclusion of the broader political situation. On the contrary, the sources show that seafarers explicitly drew attention to the identity they shared with coreligionists and reacted to major national events as much as to specific maritime ones. They were hardly 'outcasts'. However, the stereotype of the 'seaman' should not be discounted, for seafarers themselves played upon it in their public actions. It is important, too, to acknowledge the substantial variety between seafarers; not all of them were religiously and politically committed, and of those that were, not all were parliamentarian in their sympathies. Yet the parliamentarians among them, some at least associated with Warwick and present both in London's eastern suburbs and the royal fleet, could not have appealed successfully in the language they did if these sentiments had been totally absent.The decision of the majority of naval sailors to support parliament in July 1642 thus fits into the longer

\footnotetext{
145 J. Adamson, 'Introduction: high roads and blind alleys - the English civil war and its historiography', in The English Civil War: Conflict and Contexts, 1640 - 9, ed. J. Adamson (Basingstoke, 2009), pp. 1 - 35, at p. 26 ; J. Morrill, 'The religious context of the English civil wars', in J. Morrill, The Nature of the English Revolution (1993), pp. 45 - 68; see also Prior and Burgess, esp. J. Morrill, 'Renaming England's wars of religion', pp. 307 -25 ; and the sources cited in the introduction, p. 9 , n. 26.

${ }^{146}$ Morrill, 'The religious context'; Fletcher, pp. 124, 417 - 18; Gentles, pp. 128 - 41; Braddick, ch. 5.
} 
development of attitudes among seafarers, not just into a narrative of officers' actions. As Warwick himself was keen to emphasize, though with obvious polemical purpose, it was the sailors who did the 'seizing'.

This study supports the argument by Lewis Fischer that to realize the field's full potential, maritime historians must give more attention to 'appropriate contexts'. ${ }^{147}$ Yet the criticism made by Fischer and others that some maritime historians remain 'locked into local or national approaches' is not entirely fair. ${ }^{148}$ Seafarers were critical figures in the increasingly globalized networks of exchange during the early modern period, key intermediaries of cultural and economic contact. They also lived within local and national frameworks, and shared identities with the society from which they originated as well as on the level of a vocational seafaring community. The two dimensions were not distinct but contributed symbiotically to one another: both form part of the vast and multifaceted story that maritime history can tell, and the real challenge is to approach both.

In 1995, Frank Broeze argued that 'Once our own house is in order and doubts about our identity and purpose are erased, the task of integrating maritime history into general history . . . can be pursued with conviction and confidence'. ${ }^{149}$ The persistence among maritime historians of a 'siege mentality' and 'sense of crisis', which Broeze noted, suggests that he had it the wrong way round. ${ }^{150}$ Only by integrating maritime history into 'general history', by engaging with the debates of other historical fields, can 'doubts about our identity and purpose' be resolved. Perhaps, in this respect, it is worth returning to David J. Starkey and Basil Greenhill's argument, made twenty-five years ago, that maritime history is not a discipline with its own methodology, but a dimension of history as a whole. ${ }^{151}$ Seafarers stand at the crux of many historical developments: to understand them we therefore need to place them in relation both to their global impact and to their relationships with society ashore. We need to see them not only aboard ship but everywhere else. We need to think outside the gundeck.

\footnotetext{
147 Fischer, 'Are we in danger', pp. 368 - 9. Fischer points out that even in recent years, over half of submissions to the International Journal of Maritime History were rejected for 'insufficient or unconvincing contextualisation'.

${ }^{148}$ Fischer, 'Are we in danger', p. 368; cf. Polónia, p. 5.

149 F. Broeze, 'Introduction', in Maritime History at the Crossroads: a Critical Review of Recent Historiography, ed. F. Broeze (St. John's, Newfoundland, 1995), pp. ix-xxi, at p. xx.

${ }^{150}$ Broeze, 'Introduction', p. xviii.

${ }^{151}$ D. J. Starkey, 'Introduction', pp. iii-vi, and B. Greenhill, 'Prologue: some thoughts on maritime history', pp. 1 - 9, both in Sources for a New Maritime History of Devon, ed. D. J. Starkey (Exeter, 1987); cf. Johnman and Murphy. However, Greenhill also argued that the 'alienation' of seafarers from society should be central to maritime history.
} 